\title{
木質接着パネル構法における勾配屋根の振動特性に関する研究
}

\section{A STUDY ON VIBRATIONAL CHARACTERISTICS OF A FULL SCALE SLOPED ROOF BY WOODEN PANELS CONSTRUCTION}

\author{
梶川久光*1, 野口弘行*2, 高岡藏子*3 \\ Hisamitsu KAJIKAWA, Hiroyuki NOGUCHI and Mayuko TAKAOKA
}

\begin{abstract}
The report describes about the effects of slope on vibrational characteristics of a roof by wooden panels construction. The full scale roofs were flat size of a $10.92 \mathrm{~m}$-long by $3.64 \mathrm{~m}$-wide and four types slopes of flat, 18-degree, 27-degree, and 45-degree. The forcing shaking test by an exciter, and free vibration test by an impulse hammer were carried out on these roofs. The dynamic shaking test showed that mode shapes were similar regardless of rise and fall of roof's slope and that natural frequencies became smaller along with roof's slope rising. Within lower de gree, the observed values agreed with the frequencies based on the shearing vibration theory, but within higher mode degree, these were lower. The frequencies from eigenvalue analysis based on the shearing vibration type were a little lower than the observed values. The mode shapes were similar to sine-curves of vibration mode of the simple beam. In time history response analysis, response displacements were bigger along with roof's sloped rising, because of fall of horizontal stiffness. The effect of slope's degree was susceptible to weight.
\end{abstract}

Keywords: Full Scale Vibration Test, Sloped Roof, Horizontal Diaphragm, Shearing Behavior, Eigenvalue Analysis, Time History Response Analysis 実大振動実験, 勾配屋根, 水平構面, せ九断挙動, 固有值解析, 時刻歴応答解析

\section{1 研究目的}

これまで水平力に対して高いせん断剛性と強度を有する水平構 面として、木質ダイヤフラムの研究が数多くなされてきたが、そ のほとんど全てがダイヤフラムの静的性状を対象としたものであ る。しかし、本来、ダイヤフラムに作用する面内力は地震力や風 圧力など動的な荷重によるものである。従って、建物全体の動的 挙動を踏まえた力学的性状を検討する上で、ダイヤフラムの振動 特性を明らかにすることは必要不可欠であると考えられる。また、 既往の研究では屋根の勾配の差異に関する研究がほとんどないの が現状である。しかし、屋根は勾配により 3 次元的になることか ら、動的荷重を受けた際、無勾配の場合には見られない挙動 (屋根 面が面外に振動するなど) も含んでいると考えられる。

そこで、本研究では、図 1 に示すように、平面寸法 10,920mm $\times 3,640 \mathrm{~mm}$ の実大屋根の勾配を、 $0^{\circ} 、 18^{\circ} 、 27^{\circ} 、 45^{\circ}$ の 4 夕 イプに変化させ、静的水平加力実験、起振機加振実験、自由振動実 験及びインパルスハンマー加振実験という様々な振動実験を行う ことにより、屋根の勾配による影響を実験的観点から把握する。そ して、静的加力実験から得られた実験値により固有值解析及び梁 振動理論による計算を行い、振動実験の実験結果と比較検討する。 さらに、奉地震波による時刻歴応答解析を行うことにより、屋根勾
配の影響を考慮した振動特性について、総合的に解明することを 目的とする。

\footnotetext{
*1 明治大学大学院 博士後期課程 $\cdot$ 工修 (ミサワホーム侏構造技術グループ)

*2 明治大学理工学部建築学科 教授・工博

*3 明治大学大学院 博士前期課程
}

Graduate Student, Dept. of Architecture Graduate School of Science Technology, Meiji Univ., M. Eng.

Prof., Dept. of Architecture School of Science Technology, Meiji Univ., Dr. Eng. Graduate Student, Dept. of Architecture Graduate School of Science Technology, Meiji Univ. 


\section{2 実大勾配屋根の動的水平加振実験}

実験の概要を図 1 に示した。実験はミサワホーム松本実験セン ターにて行われ、2001 年に $0^{\circ} 、 18^{\circ} 、 27^{\circ}$ の 3 体 $^{12) ~ 14) 、 2002 ~}$ 年に $0^{\circ} 、 45^{\circ}$ の 2 体 $^{16) \sim 18)}$ の動的加振実験を行ったが、 $0^{\circ}$ につ いては 2001 年と 2002 年で重複しているため、検討には 2002 年 のデータを用いた。

\section{1 試験体等}

\section{1 .1 座標軸の設定}

図 1 と図 3 に座標軸の設定を示す。座標軸はモジュールを $910 \mathrm{~mm}$ とし、桁行き方向を $\mathrm{X}$ 軸、梁間方向を $\mathrm{Y}$ 軸、鉛直方向を $\mathrm{Z}$ 軸と 設定した。

\subsection{2試験体}

試験体図を図 3 に示す。試験体は木質接着複合パネルにより構 成される平面寸法 $10,920 \mathrm{~mm} \times 3,640 \mathrm{~mm}$ の実大勾配屋根であ る。試験体の構成は鉄骨架台の上にローラーを介して LVL 材れ1 $(90 \mathrm{~mm} \times 303 \mathrm{~mm})$ をL 型鋼板を介してラグスクリューで固定し 組み立てた。その上に屋切パネル ${ }^{\sharp 2}$ を建てウレタン系接着凨と釘 により接合した。次に屋切パネルの棟位置に鋼製梁をかけた。その 上に屋根パネル 2 を敷き並べ、釷のみで接合した。また、屋根パ ネルの周囲には、曲げモーメントに抵抗する部材として趗し材 ${ }^{43}$ （枠組壁工法においての鼻隠し、破風板、棟木に相当する ${ }^{8)}$ ) を接 着剤及び釘により取り付けた。試験体は X0 通り及び X12 通りで 水平方向 $(\mathrm{Y}$ 方向) に固定し、X0、X3、X6、X9、X12 通りの両 端は鉛直方向を固定し浮き上がりを防止した。

次に試験体一覽を表 1 に示す。屋根勾配は $0^{\circ} 、 18^{\circ} 、 27^{\circ} 、 45^{\circ}$ の 4 種類であり、モデル形状は棟位置で屋根構面が分割されてい ないモデルを一枚割り（SNG）、棟位置で屋根構面が二つに分割さ れているモデルを二枚割り（DBL）とした 2 種類であり、合板厚 は $9 \mathrm{~mm} の 1$ 種類である。積載については無積載タイプと有積載 タイプがあり、有積載タイプの場合は、重さ約 $2.73 \mathrm{kN} /$ 枚、厚さ 約 $40 \mathrm{~mm}$ の鉄板 8 枚 (総重量約 $21.84 \mathrm{kN}$ ) を、屋根パネルに配置 し、受け材を打ち付けて固定した。従って、試験体は形状の異なる もので 4 種類、積載の有無で計 7 種類となる。

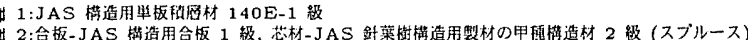

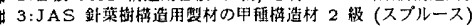

\subsection{3 試験体名}

試験体名の設定を図 2 に示す。試験体名の左から、モデル形状、 合板厚、屋根勾配、積載の有無、加振位置を表す。

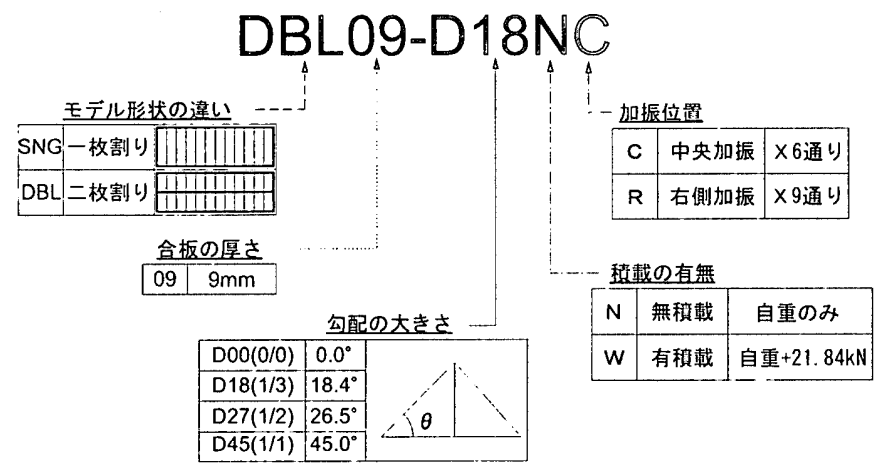

図 2 試験体名の設定

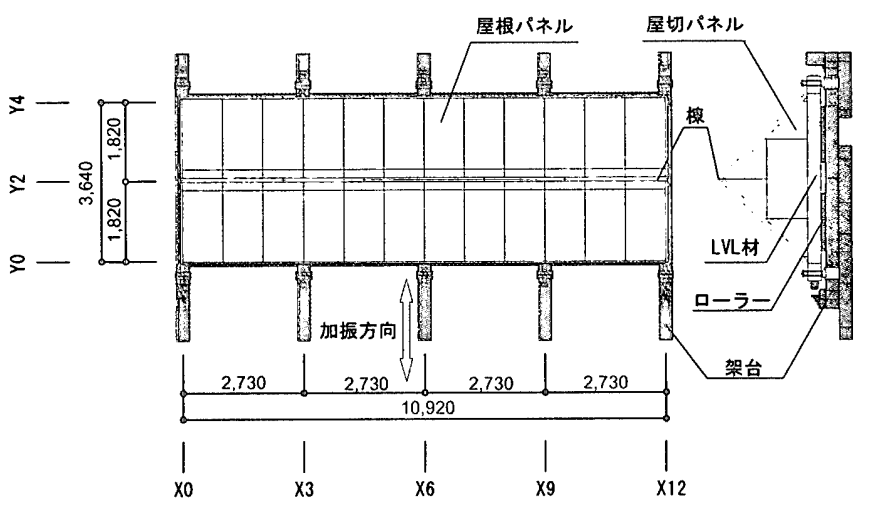

図 3 試験体図

表 1 試験体一覧

\begin{tabular}{|c|c|c|c|c|}
\hline 試験体名 & 勾配 & モデル形状 & 試験体図 & 積㦳 \\
\hline \multirow{2}{*}{ SNG09-D00 } & \multirow{2}{*}{$0^{\circ}$} & \multirow{2}{*}{ 一枚㓶り } & & 有 \\
\hline & & & 11 & 無 \\
\hline \multirow[b]{2}{*}{ DBL09-D18 } & \multirow{2}{*}{$18^{\circ}$} & \multirow{2}{*}{ 二枚割り } & DIIT & 有 \\
\hline & & & II! & 無 \\
\hline DBL09-D27 & $27^{\circ}$ & 二枚割り & III & 無 \\
\hline \multirow{2}{*}{ DBL09-D45 } & \multirow{2}{*}{$45^{\circ}$} & \multirow{2}{*}{ 二枚割り } & \multirow{2}{*}{ 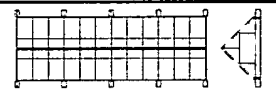 } & 有 \\
\hline & & & & 無 \\
\hline
\end{tabular}

\section{2 実験方法}

実験は起振機加振実験、自由振動実験及びインパルスハンマー 加振実験の 3 種類を行った。振動モードを明確に捉えるために、加 振位置を X6 通り（中央加振）及び X9 通り（右側加振）の位置で 2 通りの加振を行った。

\subsection{1 起振機加振実験}

《目的》起振機加振実験はスイープ加振により共振曲線を描き、 共振時の変形図、固有振動数及び減衰定数を求めるために行った。 《加振方法》加振は、LVL 材及び合板の補助部材により構成さ れる起振機台（図 5、図 6）に設置した起振機（株式会社サンエス） （重量約 343N）により行った。扣振制御は、最大加速度 500 gal の 正弦波を $1.0 \mathrm{~Hz} \sim 50.0 \mathrm{~Hz}$ の範囲において $1.0 \mathrm{~Hz}$ 刻みで行い、共 振点と思われる付近においては $0.05 \mathrm{~Hz}$ 刻みで行った。

《測定方法》一例として試験体 DBL09-D18R における測定位 置図を図 4 に示す。測定はX0、X3、X6、X9、X12 通り及びその 中間部の屋根パネル上の端部 $(\operatorname{ch} 1 \sim \operatorname{ch} 9)$ 、起振機付近の起振機台 上 (ch10) 及び起振機上 (ch11) に加速度計（リオン株式会社）を 設置し、加振方向 (Y 方向) の加速度を測定した。また、X3、X6、 X9 通り及びその中間部（ch12〜 ch16）にはレーザー変位計（株 式会社キーエンス）を設置し、変位を゙測定した。データは起振機 の波形が安定してから、デジタル動ひずみ測定器（東京測器研究 所）をパソコンで制御し、サンプリング周波数 $500 \mathrm{~Hz}$ で 5 秒間収 録した。 


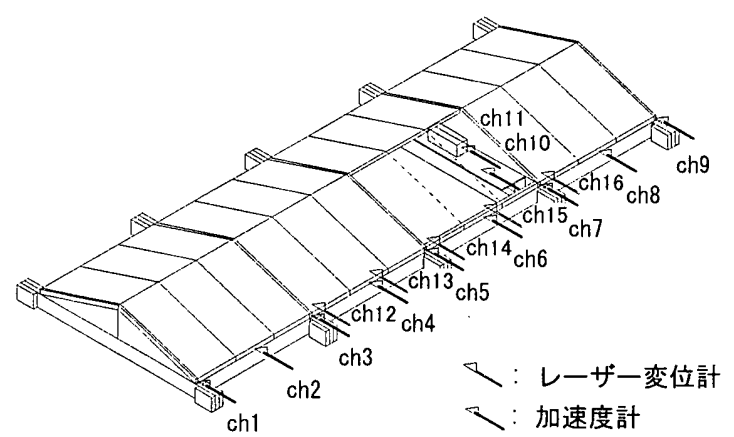

図 4 起振機加振実験測定位置図（例：DBL09-D18R）

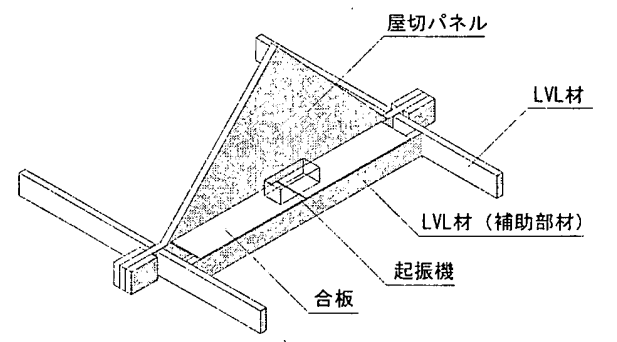

図 5 起振機台概要図

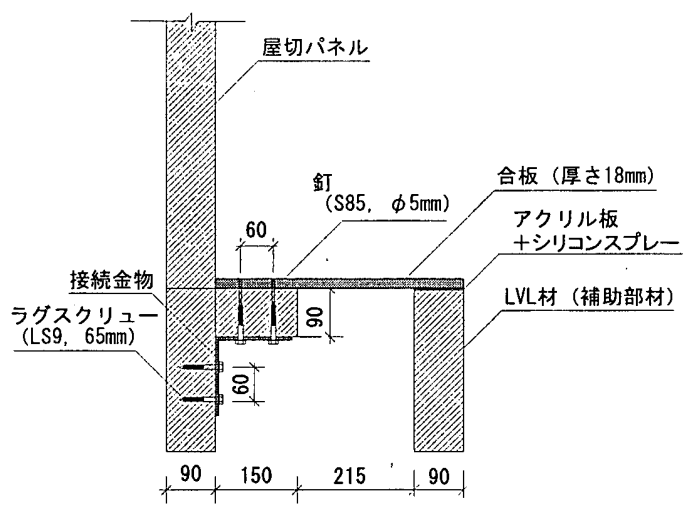

図 6 起振機台断面詳細図

\subsection{2 自由振動実験}

《目的》自由振動実験は固有振動数及び減衰定数を求めるため に行った。

《加振方法》自由振動実験は起振機により共振点と思われる振 動数で試験体を摇らし、一気に加振を停止させる方法で自由振動 を起こし、加速度及び変位を測定した。

《測定方法》測定位置については起振機加振実験と同様である。 測定方法は起振機による加振が安定してから測定を開始し、一気 に加振を停止させて試験体の振動が停止するまで測定した。デー 夕収録は起振機加振実験と同様である。

\section{2 .3 インパルスハンマー加振実験}

《目的》インパルスハンマー加振実験は、伝達関数を測定し、そ の值を用いてモード解析を行い、固有振動数、固有モード及び各 モードにおける減衰定数を得ることを目的とした。

《加振方法》インパルスハンマー加振赛験は、図 1 に示す加振 位置（X6、X9）の加力桁をインパルスハンマー（PCB 社）で一 定間隔で打撃加振し、数回の平均化処理を施した。

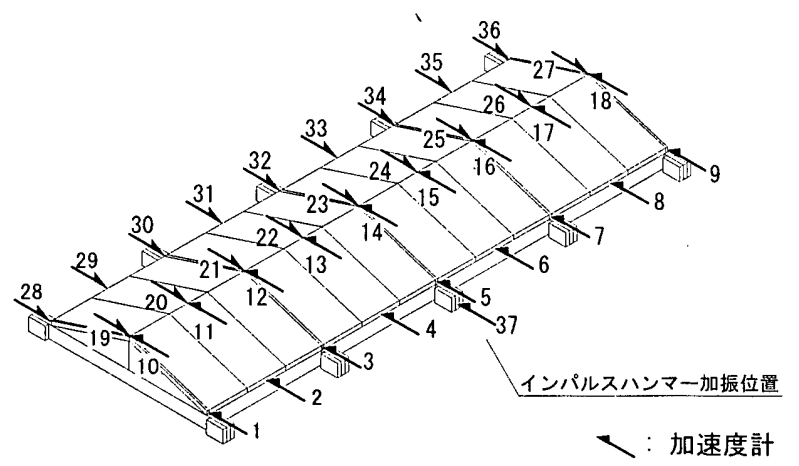

図 7 インパルスハンマー加振実験測定位置図（例:DBL09-D18C）

《測定方法》試験体 DBL09-D18C における測定位置図を図 7 に示す。压電式加速度計（リオン株式会社）を測定点に設置した アングルに磁力で固定して、各点の伝達関数を測定した。測定は 多チャンネル分析処理器（リオン株式会社）をパソコン制御し行つ た。また、伝達関数の信頼性はコヒーレンス関数により確認した。

\section{3 実験結果の整理}

起振機加振実験、自由振動実験、インパルスハンマー加振実験 の実験結果を共振曲線、固有振動数、減衰定数及び固有モードに ついて次ページ、表 2 に示す。なお、デー夕が得られなかったも のについては、表示をーとしてある。

\subsection{1 共振曲線}

共振曲線は、横軸が起振機上の加速度計（ch11）の振動数、縦 軸が $\operatorname{ch} 1 \sim \operatorname{ch} 9$ までの応答加速度の平均值を起振機の平均加速度 （ch11 - ch10）で除した加速度応答倍率である。なお、共振曲線 上の数値はモード次数を表している。

\subsection{2 固有振動数}

起振機加振実験の固有振動数は描いた共振曲線のピーク位置よ り求め、自由振動実験では 1 次〜 4 次モードの加速度時刻暦波形 の山と山（谷と谷）の間隔（時間）の逆数の平均值として求めた。 インパルスハンマー加振実験は、測定した伝達関数を用いて、実 験モード解析ソフトウェア（VIBRANT：丸紅ソリューション株 式会社）により固有振動数を求めた。

\subsection{3 減衰定数}

起振機加振実験では共振曲線からハーフパワー法を用いて、自 由振動実験では 1 次 4 次モードの加速度時刻歴波形から対数減 衰率により、減衰定数を求めた。インパルスハンマー加振実験では 固有振動数と同様、モード解析により求めた。

\subsection{4 固有モード}

起振機加振実験では 1 次〜 4 次モードで加速度応答倍率が最大に なる点と同時刻の応答加速度を 2 階積分して変位を算出し、（レー ザー変位計によって测定された変位と整合させつつ）変形図（固有 モード）を描いた。インパルスハンマー加振実験においては、前述 の実験モード解析ソフトウェアを用いて、各固有モードをアニメー ション表示した。 
表 2 結果一覧; 左

\begin{tabular}{|c|c|c|c|c|c|c|c|c|c|}
\hline \multirow{3}{*}{ 斌毁体名 } & \multicolumn{9}{|c|}{ 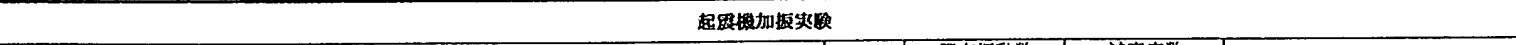 } \\
\hline & \multicolumn{2}{|c|}{ 並扳曲線 } & \multirow{2}{*}{ 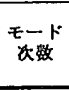 } & \multicolumn{2}{|c|}{$\begin{array}{l}\text { 固有坂怔 } \\
\mathrm{f}[\mathrm{Hz}]\end{array}$} & \multicolumn{2}{|c|}{ 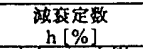 } & \multicolumn{2}{|c|}{ 固有モート } \\
\hline & 中央加报 & 右做加报 & & $\begin{array}{l}\text { 中央 } \\
\text { 加振 }\end{array}$ & 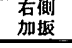 & 加退 & $\begin{array}{l}\text { 石㑡 } \\
\text { 加振 } \\
\end{array}$ & 央加报 & 右侧加振 \\
\hline \multirow{4}{*}{ SNG09-D00N } & $\prod_{0.0}^{0.8}$ & 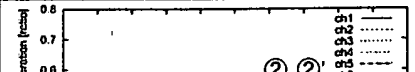 & 1. & 15.90 & 16.10 & 5.17 & 4.77 & UAD & 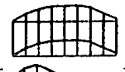 \\
\hline & 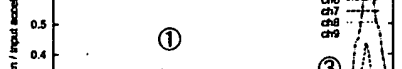 & \|\|$_{1}^{1}$ & 26 & - & 30.80 & - & 1.89 & - & t \\
\hline & & $\begin{array}{l}0.3 \\
0.2\end{array}$ & (2) & - & 34.40 & - & 1.69 & - & \\
\hline & 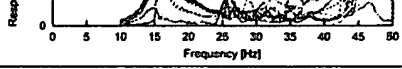 & 0 & $3 x$ & 46.00 & 46.00 & 2.51 & 2.16 & & \\
\hline \multirow{4}{*}{ SNGO9-DOOW } & (1) & (1) & 12 & 10.80 & 10.90 & 9.13 & 3.83 & 册用 & \\
\hline & (3) & (3) & $2 \gamma$ & - & 22.80 & - & 3.13 & - & IIIII \\
\hline & & & $3 x$ & 34.00 & 34.10 & 2.98 & 3.06 & IIII & LI] \\
\hline & 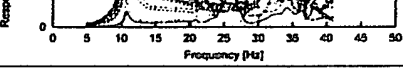 & 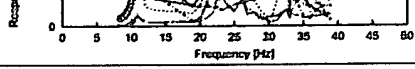 & $4 \pi$ & - & - & - & - & - & - \\
\hline \multirow{4}{*}{ DBL09-D18N } & 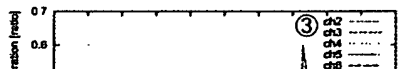 & 整 & $12 x$ & 12.10 & 12.40 & 3.01 & 8.12 & U1廾卄 & पIII \\
\hline & s. & (2) (3) (4) & $2 \nvdash$ & - & 28.75 & - & 1.01 & - & \\
\hline & & ${ }_{0.2}^{0.2}$ & $3 x$ & 37.00 & 36.75 & 1.33 & 1.79 & & \\
\hline & 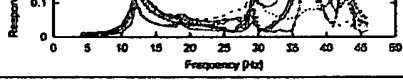 & 1. & $4 \pi$ & - & 41.00 & - & 2.63 & - & \\
\hline \multirow{4}{*}{ DBL09-D18W } & 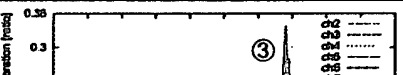 & 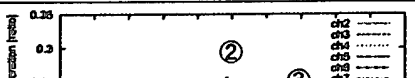 & 16 & 9.60 & 9.76 & 2.79 & 3.13 & पा工二厶 & \\
\hline & (1) & (3) & 22 & - & 24.25 & - & 3.55 & - & \\
\hline & $\left(\begin{array}{c}0.15 \\
0.1\end{array}\right.$ & $\begin{array}{ll}0 & 0.19 \\
8 & 0.1\end{array}$ & 3败 & 34.00 & 34.50 & 1.93 & 1.76 & & \\
\hline & 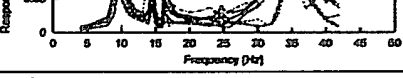 & 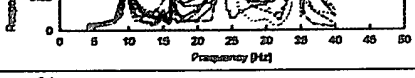 & $4 x$ & - & - & - & - & - & - \\
\hline \multirow{4}{*}{ DBL09-D27N } & (3) ${ }_{\substack{\mathbf{a} \\
\mathbf{a}}}^{\mathbf{s}} \equiv$ & (2) & $12 x$ & 11.30 & 11.70 & 2.86 & 6.28 & tEIII & पIII \\
\hline & & & $2 \%$ & - & 23.10 & - & 2.02 & - & An \\
\hline & & 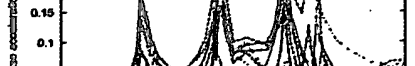 & 326 & 32.30 & 32.60 & 2.69 & 1.53 & & \\
\hline & 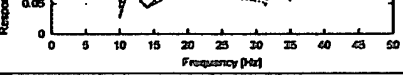 & $0_{0}$ & 4) & - & 37.10 & - & 1.72 & - & \\
\hline \multirow{4}{*}{ DBLO9-D45N } & 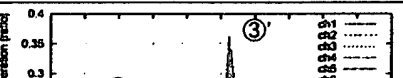 & 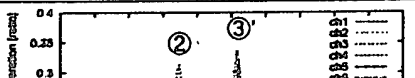 & 12 & 9.20 & 9.30 & 4.88 & 4.57 & 世\#A & \\
\hline & $\begin{array}{llll}(1) & \text { (3) } & \text { (3) } \\
0\end{array}$ & (1) & 225 & - & 17.40 & - & 3.71 & - & \\
\hline & h & a.s. & $3 x$ & 22.20 & 22.60 & 3.11 & 2.30 & WDID & \\
\hline & 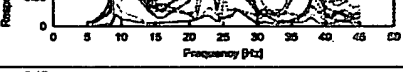 & 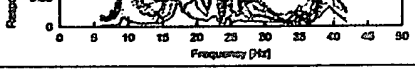 & (926) & 26.20 & 26.00 & 3.42 & 3.51 & & \\
\hline \multirow{6}{*}{ DBL09-D45W } & (3) & 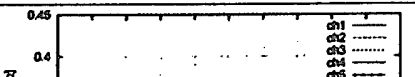 & $12 x$ & 6.25 & 6.13 & 2.68 & 3.07 & IIII & \\
\hline & 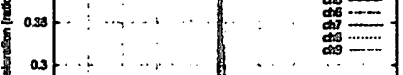 & 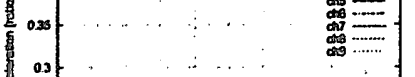 & $\begin{array}{l}(12))^{\prime} \\
\text { 面外 }\end{array}$ & - & 8.25 & - & 1.15 & - & Wfit \\
\hline & $\therefore$ 悬 & (1) $:{ }^{(2)}$ & $\begin{array}{l}\text { (1) } \\
\text { 面外) } \\
\end{array}$ & 11.30 & 11.30 & 3.65 & 3.43 & UAD & \\
\hline & (1) 1 & (1) (1) & 2狄 & - & 16.80 & - & 4.24 & - & HDI \\
\hline & Men & 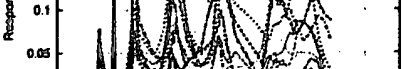 & 32א & 24.20 & 23.70 & 1.81 & 3.98 & EAyA & \\
\hline & 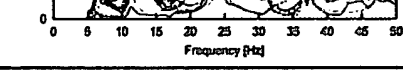 & 0 & $4 x^{2}$ & - & 32.00 & - & 4.88 & - & LDI \\
\hline
\end{tabular}


表 2 結果一覧; 右

\begin{tabular}{|c|c|c|c|c|c|c|c|c|c|c|c|c|c|c|c|c|}
\hline \multicolumn{4}{|c|}{ 自由振動实酸 } & \multicolumn{6}{|c|}{ インバルスハンマー加振実駼 } & \multicolumn{5}{|c|}{ 固有值解析 } & \multirow{2}{*}{\multicolumn{2}{|c|}{ 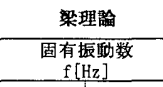 }} \\
\hline \multicolumn{2}{|c|}{$\begin{array}{l}\text { 固有振動数 } \\
\mathrm{f}[\mathrm{Hz}]\end{array}$} & \multicolumn{2}{|c|}{$\begin{array}{c}\text { 诚薏定数 } \\
\mathrm{h}[\%]\end{array}$} & \multicolumn{2}{|c|}{ 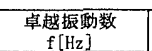 } & \multicolumn{2}{|c|}{$\begin{array}{l}\text { 诚瓘定数 } \\
\mathrm{h}[\%]\end{array}$} & \multicolumn{2}{|c|}{ 固有 $モ ー ト$} & \multicolumn{4}{|c|}{$\begin{array}{c}\text { 固有振勘数 } \\
\mathrm{f}[\mathrm{H}] \mathrm{z}]\end{array}$} & \multirow{2}{*}{$\begin{array}{l}\text { 圈有モード } \\
\text { [16分割门 }\end{array}$} & & \\
\hline 虫英 & 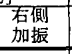 & 虫鸯 & 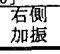 & 加握 & 䂟振 & 安加握 & 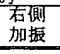 & 中央加振 & 右側加振 & 4分割 & 8分制 & 16分割 & 48分割 & & せん断型 & 曲代型 \\
\hline 15.67 & 16.74 & 4.93 & 4.14 & 16.08 & 16.06 & 3.66 & 3.87 & EIID & & 15.65 & 15.91 & 15.97 & 16.23 & 【I] & 18.02 & 63.38 \\
\hline - & 31.25 & - & 2.96 & - & 31.42 & - & 2.23 & - & AEIHE & 29.89 & 31.84 & 32.32 & 32.93 & & 36.05 & 253.5 \\
\hline - & 35.14 & - & 4.66 & 36.24 & 37.59 & 0.83 & 1.20 & EAND & & - & - & - & - & & - & - \\
\hline 47.92 & 46.94 & 3.25 & 3.07 & 47.56 & 46.18 & 2.68 & 4.91 & EAPYA & Eft & 38.81 & 44.77 & 46.35 & 47.50 & & 54.07 & 570.4 \\
\hline 11.13 & 10.88 & 3.57 & 4.48 & 11.57 & 11.72 & 3.60 & 3.41 & EIDA & EII & 10.35 & 10.53 & 10.57 & 10.74 & UI & 12.07 & 42.43 \\
\hline - & 22.91 & - & 5.81 & 23.56 & 22.63 & 2.18 & 4.04 & ED什变 & EAP & 19.53 & 20.90 & 21.23 & 21.62 & IIII & 24.13 & 169.7 \\
\hline 34.89 & 34.99 & 2.84 & 3.29 & 33.57 & 33.57 & 4.10 & 3.48 & EUADE & Eft & 25.65 & 30.19 & 31.32 & 32.10 & & 36.20 & 381.9 \\
\hline - & - & - & - & - & - & - & - & - & & - & 41.78 & 44.48 & 45.89 & Int & 48.26 & 678.9 \\
\hline 12.61 & 12.76 & 6.76 & 3.37 & 11.90 & 11.95 & 3.32 & 7.85 & EIID & & 11.47 & 11.66 & 11.70 & 11.90 & & 13.70 & 60.33 \\
\hline- & 27.36 & - & 2.43 & - & 26.60 & - & 5.48 & - & & 22.27 & 23.69 & 24.05 & 24.52 & & 27.39 & 241.3 \\
\hline 36.29 & 36.23 & 4.81 & 1.67 & 36.40 & 36.24 & 4.05 & 2.02 & Anft & A & 28.46 & 32.25 & 33.29 & 34.10 & & 41.09 & 543.0 \\
\hline - & - & - & - & 41.20 & 44.56 & 2.74 & 3.20 & 时借 & & - & 56.57 & 60.52 & 62.52 & & 54.79 & 965.3 \\
\hline- & 9.43 & - & 2.52 & - & 9.59 & - & 4.03 & - & 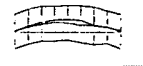 & 7.89 & 8.04 & 8.07 & 8.21 & & 9.42 & 41.48 \\
\hline- & 22.90 & - & 2.45 & - & 22.98 & - & 4.89 & - & & 14.98 & 16.09 & 16.36 & 16.69 & $\sqrt{11}$ & 18.83 & 165.9 \\
\hline- & 33.51 & - & 2.11 & - & 32.88 & - & 2.55 & - & & 19.40 & 22.82 & 23.72 & 24.34 & & 28.25 & 373.3 \\
\hline- & - & - & - & - & - & - & - & - & & - & 32.93 & 35.31 & 36.49 & & 37.67 & 663.7 \\
\hline 11.71 & 11.95 & 4.67 & 4.48 & 12.09 & 12.46 & 4.08 & 4.29 & E & & 10.59 & 10.77 & 10.81 & 11.00 & & 12.98 & 56.85 \\
\hline- & 22.73 & - & 3.93 & - & 23.68 & - & 6.32 & - & & 20.45 & 21.81 & 22.15 & 22.58 & & 25.97 & 227.4 \\
\hline 32.43 & 32.61 & 2.61 & 3.18 & 33.23 & 33.54 & 5.57 & 3.48 & ATt & & 26.19 & 29.88 & 30.89 & 31.65 & & 38.95 & 511.7 \\
\hline & · & ' & ‘ & 38.15 & 38.23 & 0.98 & 0.55 & Eftits & & - & 50.58 & 54.36 & 56.18 & & 51.94 & 909.7 \\
\hline 9.07 & - & 4.21 & - & 9.57 & 9.61 & 5.15 & 6.51 . & EIDA & EIIDA & 8.71 & 8.86 & 8.90 & 9.06 & & 11.92 & 51.71 \\
\hline - & 17.33 & - & 3.42 & 17.87 & 17.91 & 6.12 & 1.17 & A培A & & 16.70 & 17.85 & 18.14 & 18.50 & MID!: & 23.85 & 208.9 \\
\hline 22.28 & 22.69 & 3.32 & 3.86 & 22.33 & 21.69 & 2.17 & 2.69 & Affit & ANAD & 21.42 & 24.63 & 25.51 & 26.16 & & 35.77 & 465.4 \\
\hline 26.51 & 25.62 & 2.90 & 6.30 & 24.92 & 26.21 & 8.18 & 2.11 & AFEAS & EHADI & - & - & - & - & - & - & - \\
\hline 6.62 & 6.30 & 2.86 & 4.58 & 6.54 & 6.96 & 4.00 & 5.04 & Extis & 证AD & 6.44 & 6.57 & 6.60 & 6.72 & WDITITH & 8.84 & 38.34 \\
\hline- & - & - & - & - & - & - & - & - & - & - & - & - & - & - & - & - \\
\hline 11.75 & 11.58 & 3.19 & 3.58 & 11.83 & 11.99 & 2.97 & 3.48 & EIfID & EHAD & - & - & - & - & - & - & - \\
\hline- . & 16.95 & - & 6.86 & - & 17.86 & - & 3.06 & - & ENA & 12.18 & 13.10 & 13.33 & 13.60 & (17)DIDI & 17.68 & 153.3 \\
\hline- & - & - & - & 24.01 & 23.81 & 3.43 & 3.91 & ENHE & GDiT & 15.78 & 18.61 & 19.37 & 19.38 & IITENII & 26.52 & 345.0 \\
\hline- & - & - & - & 32.92 & 31.77 & 6.76 & 1.69 & Antif & HATIDS & - & 26.74 & 28.75 & 29.77 & Indontent] & 35.36 & 613.4 \\
\hline
\end{tabular}




\section{3 固有値解析}

\section{1 解析モデル}

解析モデル ${ }^{11)}$ は図 8 に示したようなせん断変形型モデルとし、 4 分割、8 分割、16 分割、48 分割で行った。壁構面バネは無限大 (完全剛体) とした。解析モデルの種類は実験を行った勾配を $0^{\circ}$ 、 $18^{\circ} 、 27^{\circ} 、 45^{\circ}$ の 4 種類に、積載の有無による合計 8 種類である。

インプットデータとして各試験体の総重量及びせん断弾性係数 を表 3 に示す。重量は静的加力実験 $\left.{ }^{12)} 16\right)$ でロードセルにより測定 した重量を用いた。静的加力実験で得られた荷重一変位関係を図 9 に示す。せん断弾性係数 $\mathrm{G}[\mathrm{N} / \mathrm{mm}]$ （合板厚を無次元化）は、静 的加力実験から得られた荷重一変位関係の初期剛性を用いて算出 した。

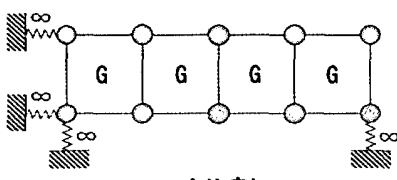

4分割

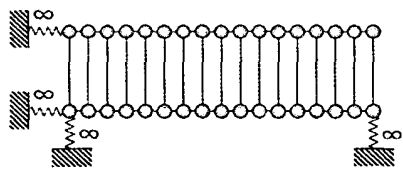

16分割

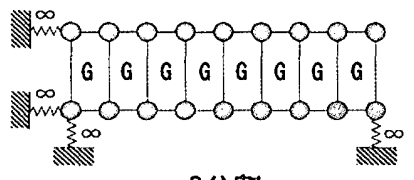

8分割

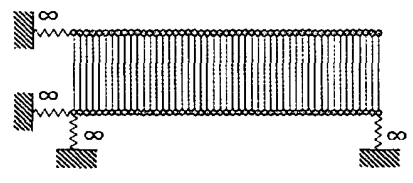

48分割
図 8 解析モデル

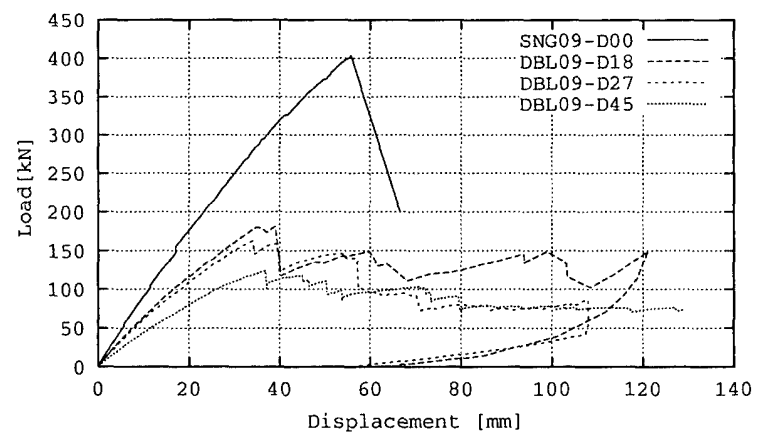

図 9 荷重一変位関係（静的加力実験）

表 3 解析インプットデータ

\begin{tabular}{c||c|c|c}
\hline 試験体名 & 勾配 & $\begin{array}{c}\text { 重量 } \\
{[\mathrm{kN}]}\end{array}$ & $\begin{array}{c}\text { せん断弾性係数 } \\
{[\mathrm{N} / \mathrm{mm}]}\end{array}$ \\
\hline SNG09-D00N & $0^{\circ}$ & 17.76 & 5719.0 \\
\hline SNG09-D00W & $0^{\circ}$ & 39.62 & 5719.0 \\
\hline DBL09-D18N & $18^{\circ}$ & 19.60 & 3460.0 \\
\hline DBL09-D18W & $18^{\circ}$ & 41.46 & 3460.0 \\
\hline DBL09-D27N & $27^{\circ}$ & 22.07 & 3302.9 \\
\hline DBL09-D27W & $27^{\circ}$ & 43.93 & 3302.9 \\
\hline DBL09-D45N & $45^{\circ}$ & 26.68 & 2662.9 \\
\hline DBL09-D45W & $45^{\circ}$ & 48.54 & 2662.9 \\
\hline
\end{tabular}

\section{2 解析結果}

固有值解析における固有振動数、固有モードを実験結果と合わ せて表 2 に示す。固有モードは、どの分割数のモデルにおいても 1 次〜4 次モードの形状が変わらないため 16 分割のものを示した。

\section{4 梁理論による検証}

無勾配の水平構面の面内せん断性状は、連続体のせん断振動に 類似していることが報告されている。10) ここでは、実験値と梁理 論による計算值と比較することにより、有勾配の水平構面の場合で も梁理論を用いることが有効であるのかを検討する。

\section{1 梁理論概要}

一般に、両端をピン支持された連続体（単純梁）の固有振動数 はせん断振動（以下せん断型）の場合には式 (1)、曲げ振動（同、 曲げ型）の場合は式 (2) と表される。2)4)10）表 2 にせん断型と曲 げ型の梁理論による計算値を示した。

$$
\begin{aligned}
& f_{n}=\frac{n}{2} \sqrt{\frac{G \cdot A / \kappa^{\prime}}{W / g \cdot l}} \\
& f_{n}=\frac{n^{2} \pi}{2} \sqrt{\frac{E I}{\left.(W / g) \cdot l^{3}\right)}}
\end{aligned}
$$

\begin{tabular}{|c|c|}
\hline$f_{n}$ & $n$ 次の固有振動数 \\
\hline$n$ & モード次数 \\
\hline$G$ & せん断弾性保数 \\
\hline$A$ & 断面櫴 \\
\hline$\kappa^{\prime}$ & 形状係数 \\
\hline$E I$ & 曲け夙性 \\
\hline$W$ & 試験体総重量 \\
\hline$g$ & 重力加速度 \\
\hline 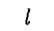 & 試験体スパン \\
\hline
\end{tabular}

\section{2 実験値と梁理論による計算値との比較及び考察}

図 10 に起振機加振実験の固有振動数とせん断型及び曲げ型の梁 理論による固有振動数を示す。実験結果はせん断型に類似している が、曲げ型とはかけ離れている。1 次については実験值とせん断型 はよく一致している。無勾配の SNG09-D00 においては、実験値 は直線的であり、せん断型の性状を表している。また、有勾配の有 積載タイプにおいても、実験值は直線的であり、せん断型の性状を 表している。一方、有勾配の無積載タイプにおいては、モ一ド次数 が高くなると実験值がせん断型よりも低くなり曲線になっている。
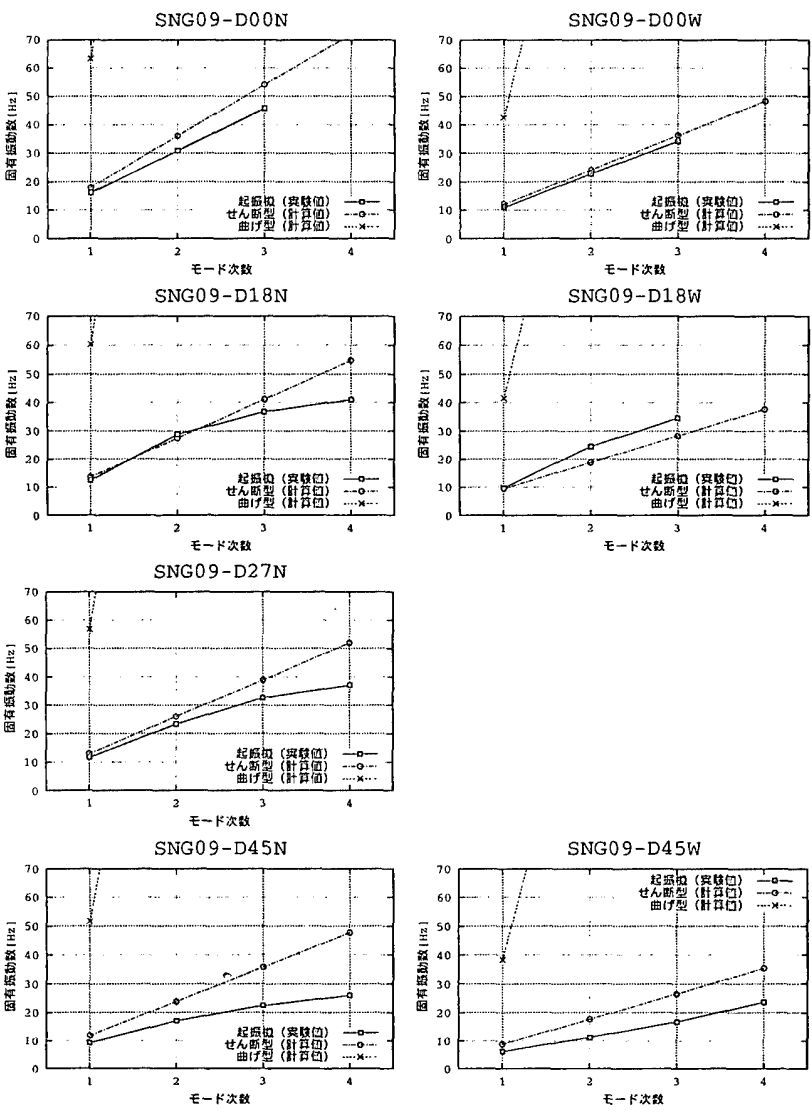

図 10 固有振動数とモード次数の関係 


\section{5 表 2 結果一覧について考察と検討 \\ 5.1 共振曲線}

共振曲線では、中央加振で 2 次の共振点が見られないが、これ は加振位置が節に当たり励起されないためである。屋根勾配が大 きくなると水平剛性が低下するため、また、無積載から有積載に なると屋根重量が増加することにより、ピークの山が左に移ってい る（固有振動数が低下する）。実験結果のみで見られることである が、有積載タイプで DBL09-D45W 以外は 1 次〜3 次のピークの 山がそれぞれ一つに対し、無積載タイプはすべて、2 次ないしは 3 次でピークの山が二つに割れる傾问にある。

\section{2 固有振動数}

起震機加振実験、自由振動実験及びインパルスハンマー一加振実 験における固有振動数は、実験の種類に関係なくほぼ近い値となっ ているが、DBL09-D18 以外は起震機加振実験よりインパルスハ ンマー加振箺験の方が若干高めに出る傾向にある。これは加振方 法の違いにより振動している変位量が異なるためである。中央加 振と右側加振では、ほぼ同じ值となっている。屋根勾配が大きく なるにつれて固有振動数は低下しており、具体的には無積載夕イ プでは無勾配の SNG09-D00 が $15.90 \mathrm{~Hz}$ であり、屋根勾配が 45 の DBL09-D45 で 9.20Hz まで低下する。さらに、有積载タイプ では同じく $10.80 \mathrm{~Hz}$ から $6.25 \mathrm{~Hz}$ まで低下する。これは水平剛性 が低下したためと、屋根重量が増加した結果である。

実験値と梁理論による計算値を比較すると、1 次において若干 せん断型の方が高めに出ているが実験值と近い値となっている。一 方、曲げ型は実験値とはかけ離れている。固有值解析による固有振 動数は分割数が多いほど、だんだん高くなりつつ実験值に近づく。 5.3 固有モード

起振機加振実験、インパルスハンマー加振実験及び固有值解析 における固有モードは、屋根勾配の大きさ、積載重量の有無、加振 位置に関係なく、おおむね連続体のせん断振動の振動形（単純梁の 規準振動形）と同じ傾向にある。

屋根公配が大きく有積載の DBL09-D45W では、(1)'(1)”のよ うに屋根構面のパネルが面外に振動している。これは、屋根勾配 が大きくなると屋根構面の面外方向にも慣性力が働き、その方向 ヘパネルの変形が誘発されやすくなるためである。

また、無積載タイプで見られるピークの山が二つに割れること に関しては、無積載の SNG09-D00N の(2)と(2) や DBL09-D45N の(3)と(3)'の固有モードによると、外形は連続体のせん断振動の振 動形に近いが、パネル個々の変形状態が異なっている。

\section{4 減衰定数}

減衰定数については、起振機加振実験、自由振動実験及びイン パルスハンマー加振実験の結果から 1 次については無積載タイプ より有積載タイプの方が若干低い傾向にあるが、全体的に見ると、 屋根勾配の大きさ、実験の種類、加振位置に関係なく、おおむね 3 〜6\%の値となっている。

\section{6 時刻歴応答解析}

\section{1 解析概要}

時刻歷応答解析 ${ }^{11)}$ は、実地震波が勾配屋根の面内振動に与える 影響を把握するために行った。
解析モデル及び試験体の種類は 3.1 と同様とし、16 分割で行っ た。重量及び岡性配分も 3.1 と同様にし、粘性減衰定数は 5.4 の 起振機加振実験、自由振動実験及びインパルスハンマー加振実験 の実験結果から、一律 $5.00 \%$ とした。入力地震波は EL-Centro、 HACHINOHE、TAFT の 3 波とし、最大速度が Level2 相当の 50[kein] となるように加工し、使用した。

\section{2 解析結果及び検討}

図 11 に横軸を屋根勾配にして、試験体 X6 通りの最大応答変位 をプロットしたものを示す。また、EL-Centro 波入力による最大 応答時 (X6 通り) の変形図を表 4 に示す。

地震波による応答は、1 次モードが卓越した変形となっている。 屋根勾配が大きくなるにつれて応答変位は大きくなっており、積 載の有無については有積載夕イプの方が応答変位が大きい。地震 波の種類による影響では、3〜 $4 \mathrm{~Hz}$ の振動数成分を多く含んでいる EL-Centro、2 3Hz の TAFT、1 2 $\mathrm{Hz}$ の HACHINOHE の 3 波に対して、特に ELL-Centroで大きな応答を示した。

無積載

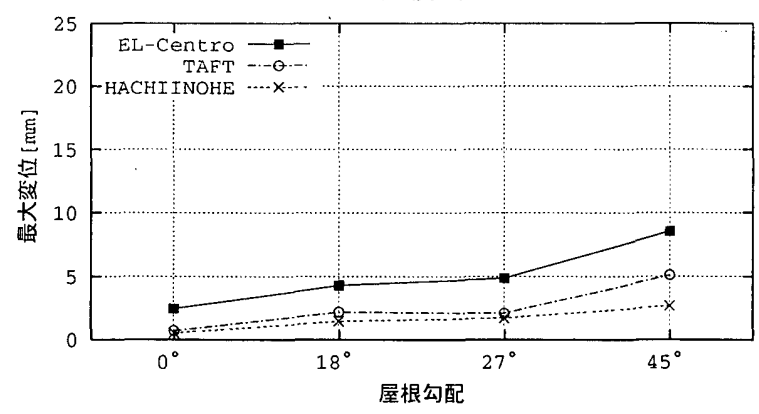

有積載

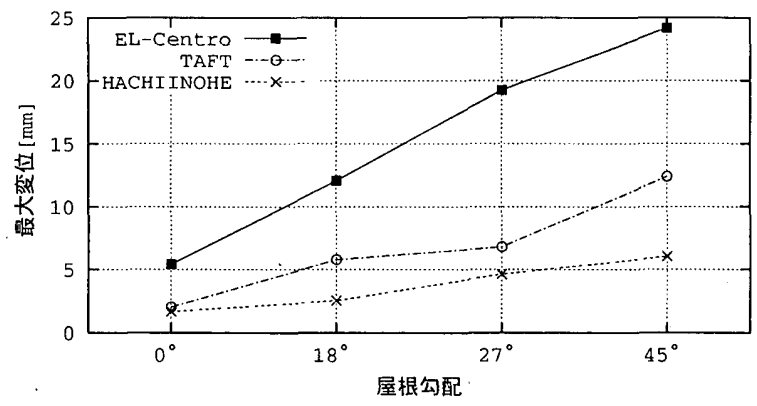

図 11 最大応答値

表 4 最大応答変形図 (EL-Centro)

\begin{tabular}{|c|c|c|}
\hline 試験体名 & $\begin{array}{l}\text { 無糟载 } \\
\end{array}$ & 有積載 \\
\hline SNG09-D00 & & \\
\hline DBL09-D18 & & \\
\hline DBL,09-D27 & & \\
\hline DBL09-D45 & & \\
\hline
\end{tabular}




\section{7 まとめ}

本研究では屋根勾配による影響について、振動特性の観点から 以下のように結論付ける。

\section{共振曲線}

・屋根勾配が大きくなるほど、また、屋根重量が増加するほどピー クの山が左に移る (固有振動数が低下する)。

・無積載タイプでは、2 次ないし 3 次でピークの山が二つに割れ る。この点のメカニズムの解明については今後の課題として取り 組みたい。

\section{固有振動数}

・無積載タイプでは SNG09-D00 の $15.90 \mathrm{~Hz}$ から DBL09-D45 の $9.20 \mathrm{~Hz}$ まで低下する。さらに、屋根重量が増加すると同じく $10.80 \mathrm{~Hz}$ から $6.25 \mathrm{~Hz}$ まで低下する。

・勾配屋根においては、せん断型の計算值は実験値と近い（1 次 モードにおいて）が、曲げ型はかけ離れる。

・固有値解析による固有振動数は分割数が多いほど、だんだん高 くなりつつ実験值に近づく。

固有モード

・固有振動モードはおおむね連続体のせん断振動の振動形（単純 梁の規準振動形）と同じ傾向になる。

・屋根勾配が $45^{\circ}$ のように大きくなると、屋根構面が面外に振動 する固有モードが出現する。この点については、屋根構面の面外 振動を考慮した振動モデルを確立することを今後の課題として取 り組みたい。

\section{減衰定数}

・1 次については無積載タイプより有積載タイプの方が若干低い傾 向にあるが、おおむね 3〜6 \%の值となっている。

\section{時刻歴応答解析}

・1 次モードが卓越しており、屋根勾配が大きくなるほざ、また、 屋根重量が大きいほど充答変位が大きくなる。特に EL-Centro 地 震波で大きな応答となった。

\section{8 問題点と今後の課題}

本研究では、屋根勾配が大きくなるほど、また、屋根重量が増 加するほど固有振動数の大幅な低下が見られた。さらに、屋根重 量の重い瓦屋根などを想定すると、数 $\mathrm{Hz}$ 低下すると予測され、建 物の水平固有振動数と近くなる。そのため、建物の振動性状にお いて水平構面の面内振動が影響してくると考えられる。この点の 検討についてさらに研究を進めることが課題として挙げられる。

なお、本研究の一部は、平成 10 年 14 年度の文部省学術フロンティア推進 事業の重点研究費 :「激震動を受ける建築構造物及び機器・装置の甪震性能の向上 化」(研究代表者: 洪忠蜜) 及び平成 12 年度よりの文部科学省科学研究費補助金 (基盤研究 A)：〔直下地震に対する部枋、架構の耐握性能向上に関する研究〕(研 究代表者 : 野口弘行) によった。

謝辞 本研究の実験実施にあたり、明治大学理工学部建築学科木質構造研究室の 2001 年度及び 2002 年度の卒業生諸氏に感謝します。特に、中心的に活動して 頂いた同研究室 2001 年度修了の伊藤修一氏、2002 年度修了の大浦和香子氏、 福間崇博氏、ミサワホーム (侏) の三津橋歩氏に多大なる感謝の意を表します。
4）大崎順彦：建築振動理論，森北出版株式会社,1996

5）杉山英男：木質構造 第 3 版，共立出版株式会社,2001

6）国土交通省住宅局建築指道䂺，国土交通省住宅局木造住宅振興室：木造軸組 工法住宅の許容応力度設計, 日本住宅・木材技術センター,2001

7）日本建築学会: 木質構造計算基準・同解説，丸善株式会社, 2002

8）日本ツーバイフォー建築協会：2002 年枠組壁工法建築物構造計算指針，株 式会社工業調查会, 2002

9）野口弘行, 鈴木秀三, 神谷文夫, 河合誠, 木上浩, 杉本健一, 那須秀行, 黒岩 保彦，岡田圭一郎，落海一哉，沼川次郎：木質系ダイアフラムの研究 (1) (9)，日本建築学会学術講演梗概集,pp. $97 \sim 114,1992.8$

10）鈴木秀三，藤野栄一，野口弘行：木質ダイアフラムの面内振動特性に関する研 究 (第 1 報)，日本建築学会構造系論文集 No.468, pp.119 126,1995.2

11）野口弘行，柅川久光: 木質半剛接ラーメン構造の振動性状に関する研究（第 1 報）水平满面の面内剛性の影響について，日本建築学会構造系論文集 No.488,pp.117 126,1996.10

12）岩崎喊司，柅川久光，福間崇博，小川春彦，三津橋歩，千原勝幸，平田俊次，野 口弘行: 屋根勾配 (水平構面) の面内せん断举動に関する研究 〜その 1 実験的検証 ， 日本建築学会学術講演梗概集,pp.171 172,2002.8

13）小川春彦、柅川久光, 福間崇博, 岩崎誠司, 三津橋歩, 鶴田修, 平田俊次, 野口 弘行 : 勾配屋根 (水平構面) の面内女九断举動に関与る研究 〜その2・解 析〜，日本建筑学会学術講演梗概集,pp.173 174,2002.8

14）大浦和香子，野口弘行，棍川久光，伊藤修一，三津橋歩，千原勝幸：水平構面 (屋根) の振動特性に関する研究 〜その $1 \cdot$ 実験的研究〜, 日本建策学会学 術講演梗概集,pp.425 426,2002.8

15) 柅川久光, 野口弘行, 大浦和香子, 高岡蒱子, 鶴田修, 平田俊次 : 水平满面 (屋 根) の振動特性に関する研究〜その 2 ・固有值解析〜，日本建築学会学術 講演梗概集,pp.423 424,2002.8

16）棍川久光, 小川春彦，高岡糊子，三津橋歩，野口弘行：木質接着パネル構法に おける有勾配屋根の水平挙動に関する研究 〜その 1 ・研究概要〜，日本建 築学会学術講演梗概集, pp. $231 \sim 232,2003.9$

17）小川春彦，握川久光，高岡藏子，三津橋歩，野口弘行：木質接着パネル構法に おける有勾配屋根の水平举動に関する研究 〜その $2 \cdot$ 水平加力実験及び検 討〜，日本建築学会学術講演梗概集,pp.233 234,2003.9

18）高岡蒱子，棍川久光，小川春彦，三津橋歩，野口弘行：木質接着パネル構法に おける有勾配屋根の水平挙動に関する研究 〜その 3 .動的加振実験及び解 析による振動特性に関する検討〜，日本建筑学会学術講演梗概集,pp.235〜 $236,2003.9$

（2003年 5 月 9 日原稿受理，2003年 9 月 8 日採用決定）
参考文献

1) 杉山英男：建築構造学大系 木構造, 彰国社,1966

2）志賀敏男：構造物の振動，共立出版株式会社,1976

3) 日本建築学会 : 木質構造計算ノ一ト, 丸善株式会社, 1995 